\title{
Yrkesrelevant skoleopplæring for fremtidens mediegrafikere
}

Nina Aakernes and Hilde Hiim

\begin{abstract}
Abstrakt
Høsten 2020 skal det innføres en ny struktur for yrkesfagene i videregående skole, og nye læreplaner skal utarbeides. Det skal opprettes et nytt yrkesfaglig utdanningsprogram for IKT og medieproduksjon. Dette utdanningsprogrammet skal inneholde flere lærefag og blir dermed bredere enn det «gamle utdanningsprogrammet» for medier og kommunikasjon (MK).
\end{abstract}

I denne artikkelen presenterer vi resultater fra en toårig kvalitativ studie som har undersøkt kompetansebehovet i mediegrafikerfaget og yrkesrelevansen av dagens skoleopplæring for mediegrafikerlæringene. Studien har fulgt syv lærlinger i mediegrafikerfaget fra lærekontrakt ble inngått og frem til svenneprøven. Grunnlaget for resultatene som blir presentert i artikkelen er observasjoner i lærebedriftene og tilsammen 34 semistrukturerte intervjuer med lærlinger, yrkesfaglærere, instruktører i bedrift og representanter for opplæringskontor. Resultatene viser hvilken kompetanse som er sentral i mediegrafikerfaget, og styrker og svakheter ved dagens skoleopplæring. Disse resultatene peker mot hva som skal til for å oppnå en yrkesrelevant utdanning av mediegrafikere i det nye programmet.

Emneord: yrkesfaglig opplæring, yrkesrelevans, yrkesdidaktikk, mediegrafiker, medieproduksjon 


\section{Innledning}

\section{Bakgrunn og forskningsspørsmål}

Nyere forskning viser at skoleopplæringen både på VG1 og VG2 i norske yrkesfaglige utdanningsprogram generelt sett ikke er tilstrekkelig relevant for yrket den enkelte elev $\emptyset$ nsker å utdanne seg til (Bødtker-Lund, Hansen, Haaland \& Vagle, 2017); Dahlback, Hansen, Haaland og Sylte (2011); (Hiim, 2015). En yrkesrelevant opplæring er opplæring som er forankret i yrkenes arbeidsoppgaver og kompetansebehov (Hiim, 2017; Hiim \& Hippe, 2001). Den store bredden av yrker som inngår i hvert enkelt program gjør spesialisering mot det enkelte yrket vanskelig. De nåværende læreplanene er svært generelle og tolkes ulikt. På mange skoler er det utviklet en modell hvor elevene må bruke my av tiden på å lære litt om alle eller mange av de ulike yrkene som inngår i programmet. På andre skoler er det utviklet modeller hvor det blir lagt mye vekt på generell teorikunnskap eller generelle praktiske oppgaver med uklar relevans for det enkelte yrke. Begge deler gjør det vanskelig for elever å utvikle begynnende yrkeskompetanse i et spesifikt yrke og medfører at elevene ikke føler seg rustet til læretiden (Bødtker-Lund et al., 2017; Hiim, 2013). Det er imidlertid også eksempler på modeller hvor opplæringen i relativt stor grad er organisert omkring yrkesoppgaver gjennom nært samarbeid mellom skole og arbeidsliv, og hvor elevene får muligheter til å spesialisere seg i valgt yrke (Hiim, 2013).

Utdanningsprogrammet medier og kommunikasjon fører frem til yrker i mediebransjen hvor oppgaver og kompetansebehov kan se ut til å være mindre sprikende enn i andre program (Utdanningsdirektoratet, 2016a). Skoleopplæringen har i stor utstrekning vært lagt opp som tverrfaglig prosjektarbeid hvor elevene har utviklet kompetanse gjennom arbeid med medieproduksjoner (Amdam, 2016b; Erstad, Gilje \& de Lange, 2007b).

Lærlingeundersøkelsen for både 2014, 2015 og 2016 viser imidlertid at lærlingene på MK er de som er minst fornøyd med skoleopplæringen som forberedelse til læretiden (Utdanningsdirektoratet, 2016b).

Regjeringens uttalte målsetning er at endringene i 2020 skal «gi økt faglig spesialisering og tidligere spesialisering» (Kunnskapsdepartementet, 2018, s. 1). I det nye yrkesfaglige utdanningsprogrammet for IKT og medieproduksjon skal imidlertid det fremtidige VG1 utdanne til yrker som er mindre beslektet enn yrkene i mediebransjen, noe som kan føre til nye utfordringer for spesialisering og yrkesrelevans i skoleopplæringen for mediegrafikere. Det er derfor viktig å utvikle kunnskap om oppgavene og kompetansebehovene i ulike 
mediebedrifter og hvordan relevansen av dagens skoleopplæring blir vurdert av lærlinger, instruktører og lærere, noe denne studien bidrar til. Funnene belyser hvordan en yrkesrelevant skoleopplæring for mediegrafikere kan tilrettelegges i det nye utdanningsprogrammet.

Artikkelen belyser følgende forskningsspørsmål:

Hva er kompetansebehovet i mediegrafikerfaget? Hvordan har yrkesrelevansen i dagens skoleopplaring vart? Hvordan kan yrkesrelevant skoleopplaring for mediegrafikere oppnås i utdanningsprogrammet for IKT og medieproduksjon?

\section{Den yrkesfaglige skoleopplæringen til yrker i mediebransjen}

En kort skisse over utviklingen av yrkesfaglig opplæring til mediebransjen i videregående skole kan bidra til å belyse utfordringer i utdanning av mediegrafikere. Bakgrunnen for å opprette det yrkesfaglige utdanningsprogrammet medier og kommunikasjon (MK) skoleåret 2000/2001var en rask teknologisk utvikling som medførte endringer i kompetansebehovene i mediebedriftene (Erstad, Gilje \& de Lange, 2007a). Læreplanene for MK ble fors $\varnothing \mathrm{kt}$ utformet i tråd med mediebedriftenes behov, og omfatter kompetanse i mediekommunikasjon, mediedesign og medieproduksjon innen ulike sjangre i foto, film, multimedia, lyd, og grafisk design for trykk og elektronisk publisering (Utdanningsdirektoratet, 2006).

Intensjonen med MK var å kvalifisere elevene for enten to år i lære, eller, etter VG3 medier og kommunikasjon i skole, for videre medieutdanninger på høgskolenivå. Det vil si at MK ble opprettet som en slags «hybrid» mellom yrkesfaglige og studiespesialiserende utdanningsprogram (Amdam, 2016a). Det er kun to lærefag i utdanningsprogrammet; mediegrafikerfaget og fotograffaget, og det har ikke vært noen inndeling i spesialiserte fagbrevområder på VG2.

Mediegrafikerfaget er et bredt lærefag som i tillegg til tradisjonelt førtrykksarbeid også inkluderer webdesign, multimedia- og film-produksjon. Mediegrafikere arbeider i dag blant annet i bedrifter som produserer elektroniske og trykte medier, i reklamebyråer og i filmproduksjonsbedrifter. Yrkesoppgavene handler om å designe og produsere medieproduksjoner i form av trykksaker eller digitalt materiale for skjerm, og filmproduksjon. (Utdanningsdirektoratet, 2008).

MK ble raskt et populært utdanningsprogram, og antallet elevplasser på både VG1, VG2 og VG3 økte kraftig (Frøseth, Hovdhaugen, Høst \& Vibe, 2008), mens det samtidig ikke ble opprettet flere læreplasser. Prosentandelen lærlinger har vært så lav som 3\% (Vibe, 2012). 
Det ble derfor besluttet å dele MK i et studieforberedende og et yrkesfaglig utdanningsprogram fra skoleåret 2016/2017. Det ble utarbeidet nye læreplaner for det studieforberedende programmet (Utdanningsdirektoratet, udatert). Det yrkesfaglige programmet, Medieproduksjon, beholdt de «gamle» læreplanene for MK som en overgangsordning i påvente av endringene i den yrkesfaglige tilbudsstrukturen.

I det nye utdanningsprogrammet blir det eget programområde på VG2 for medieproduksjon, og det skal opprettes et nytt lærefag for film- og videoteknikk, i tillegg til dagens fotograf- og mediegrafiker-fag. VG2 medieproduksjon skal dermed føre frem til tre fagbrevområder.

\section{Tidligere forskning}

Forskning viser som nevnt innledningsvis, at skoleopplæringen i brede norske utdanningsprogram ikke er tilstrekkelig yrkesrelevant og ikke gir gode nok muligheter for elevene til å spesialisere seg i det yrket de vil utdanne seg til (for eksempel Bødtker-Lund et al., 2017; Dahlback et al., 2011; Hansen, 2017; Hiim, 2015). Langt fra alle elever får mulighet til arbeidslivserfaring i valgt lærefag, og omfanget av samarbeid mellom skolen og arbeidslivet om opplæringen er varierende (Bødtker-Lund et al., 2017; Nyen \& Tønder, 2012).

Forskning på læreplaner i Kunnskapsløftet viser imidlertid at planene i yrkesfaglige utdanningsprogram er mer strukturert omkring helhetlige yrkesfunksjoner enn tidligere læreplaner, som i større grad var inndelt i teoretiske og praktiske skolefag (Hiim, 2013, 2015). Fokus på yrkesfunksjoner kan skape muligheter for å yrkesforankre opplæringen.

Mål og yrkesfunksjoner er imidlertid svært generelle, og det er fortsatt en delvis oppsplitting i teoretiske og praktiske fag i flere utdanningsprogram, bl.a. MK (Utdanningsdirektoratet, 2007). Læreplanene for MK er delt inn i skolefagene mediedesign, medieproduksjon og mediekommunikasjon, fag som i utgangspunktet kan være relevante for mediegrafikere dersom de blir spesifisert opp mot yrket. Skolefaget mediekommunikasjon har imidlertid nesten bare teoretiske målformuleringer, og verbene drøfte eller analysere er brukt $\mathrm{i}$ åtte av tolv kompetansemål (Utdanningsdirektoratet, 2007). Flere oppgaver og mål som inngår i faget mediekommunikasjon omhandler dessuten journalistikk og teoretisk mediekunnskap som er mest relevant for videre høgskoleutdanning (Utdanningsdirektoratet, 2007). De to andre skolefagene er derimot preget av praktiske målformuleringer som handler om hva elevene skal kunne utføre (Aakernes, 2011). 
En viktig forutsetning for yrkesrelevans og spesialisering i valgt yrke er at lærerne har fagutdanning og praksis på det aktuelle yrkesfeltet og kontakt med det lokale arbeidslivet. I brede utdanningsprogram er det en utfordring at lærerteamene ofte ikke har yrkesbakgrunn som dekker mangfoldet av yrker utdanningen fører frem til (for eksempel Dahlback et al., 2011; Dahlback, Hansen, Haaland \& Vagle, 2015; Hansen, 2017). Om lærerne har yrkesbakgrunn fra aktuelle lærefag eller utdanning fra universitet eller høgskole er dessuten avgjørende for hvordan læreplanen tolkes og for yrkesrelevansen av opplæringen (Dahlback et al., 2015; Olsen \& Reegård, 2013). Funn i Amdams forskning (2016a) viser at MKs hybride posisjon har ført til uenighet blant medielærerne om hvorvidt hovedhensikten er å gi elevene en bred, generell medieutdanning for overgang til høgskole, eller å forberede noen av dem til å bli lærlinger. I følge en nasjonal survey-undersøkelse blant medielærerne svarte kun $59 \%$ at det er viktig eller svært viktig at elevene har fått en god yrkesopplæring slik at de kan gå ut i lære eller i arbeid i mediebransjen (s. 93).

Oppsummert viser forskningen at det generelt sett er betydelige problemer med yrkesrelevansen av skoleopplæringen i brede norske utdanningsprogram. Det er imidlertid forskjeller mellom utdanningsprogram, og program med lang lærefagtradisjon (f.eks. byggfag) synes å ha bedre utviklet samarbeid med bedrifter og mer fokus på yrkesoppgaver enn program uten slike tradisjoner (f.eks. service- og samferdselsfag) (Olsen \& Reegård, 2013). Det er ikke tidligere gjennomført studier som spesifikt har undersøkt yrkesrelevansen i utdanningsprogrammet medier og kommunikasjon og i utdanningen av mediegrafikere.

Internasjonal forskning viser at utfordringer om yrkesforankring, indre sammenheng og relevans i yrkesutdanning er sentrale på tvers av utdanningsmodeller. Gessler (2017) viser til at samarbeid mellom skolen og arbeidslivet er svært mangelfullt i det tyske dualsystemet. Yrkesutdanningen er i stor grad arbeidslivsbasert og spesialisert, men skoledelen foregår løsrevet. Dette kan medføre manglende yrkesforankring og relevans i skoleopplæringen, og forbedringspotensial når det gjelder fagarbeideres teorikunnskaper. Young (2004) framhever at mangel på sammenheng mellom innholdet i arbeidslivsdelen og skoledelen av engelsk yrkesutdanning kan ha en tendens til å medføre at utdanningen som helhet blir relativt instrumentell og svakt teoretisk forankret. Louw (2017) framhever liknende utfordringer i det danske yrkesutdanningssystemet. Også Wahlgren og Aarkrog (2012) har vært opptatt av yrkesforankring og samarbeid skole/arbeidsliv. De har belyst utfordringer som gjelder overføring av kunnskap mellom læringsarenaer, og framhever viktigheten av at skole og arbeidsliv samarbeider om utdanningsinnholdet. 
En stor del av den internasjonale forskningen på yrkesutdanning retter søkelyset mot behovet for å utvikle tilnærminger som bygger på en utvidet, flerdimensjonal og helhetlig oppfatning av yrkeskunnskap og yrkeskompetanse, og det blir lagt vekt på sammenheng mellom teori og praksis og mellom læringsarenaer. Begreper som innovasjonspedagogikk, design-pedagogikk og hybrid læring handler om å utvikle utdanningsinnhold og -modeller som overskrider grensen mellom skole og arbeidsliv (Cremers, Wals, Wesselink \& Mulder, 2016; KairistoMertanen, Räsänen, Lehtonen \& Lappalainen, 2012; Zitter, Hoeve \& de Bruijn, 2016). Nærhet til yrkesoppgavene og tverrfaglig utdanningsinnhold med klar betydning for yrkesutøvelsen er sentrale prinsipper i disse tilnærmingene.

\section{Teoretiske perspektiver på kompetanse og yrkesrelevant opplæring}

En flerdimensjonal, helhetlig forståelse av kunnskap og kompetanse er utgangspunktet også for denne studien. Det har gjennom de siste tiårene vært en økende forståelse av kompleksiteten og flerdimensjonaliteten i yrkeskunnskap og av relevansproblemer som oppstår når ulike kunnskapsdimensjoner og læringsarenaer ikke henger sammen i yrkesutdanningen. Kompetansebegrepet er definert på følgende måte i Meld. St. 28 (20152016), s. 28: «Kompetanse er å tilegne seg og anvende kunnskaper og ferdigheter til å mestre utfordringer og oppgaver i kjente og ukjente sammenhenger og situasjoner». I en artikkel basert på en omfattende studie av kompetansebasert høyere yrkesutdanning blir kompetanse definert som: « et integrert sett av kunnskaper, ferdigheter og holdninger» (Koenen, Dochy \& Berghmans, 2015, s. 2). Både i denne og andre artikler blir det imidlertid framhevet at kompetansebegrepet ofte brukes både ulikt og uklart (Lester \& Religa, 2017). De fleste definisjonene handler likevel om tre forhold: kunnskaper, ferdigheter og (dels) holdninger utgjør en helhet, det dreier seg om å kunne løse oppgaver, og kompetansen skal kunne demonstreres og eventuelt måles. Kompetansebasert utdanning er en utdanning hvor autentisk oppgave- og problemløsning, fagintegrering og teori knyttet til oppgavene er hovedprinsipper (Koenen et al., 2015).

Flere forskere har fors $\varnothing \mathrm{kt}$ å utvikle teorier om hvordan disiplinbasert, teoretisk kunnskap kan kontekstualiseres i forhold til praktisk yrkesutøvelse (Heusdens, Bakker, Baartman \& De Bruijn, 2016; Young, 2004). Et hovedpoeng er at den teoretiske, disiplinbaserte kunnskapens 
betydning for yrkesutøvelsen må gjøres eksplisitt, og at dette er en sentral oppgave i yrkesutdanningen.

Hiim og Hippe (2001, s. 19) definerer yrkesdidaktikk som «praktisk-teoretisk planlegging, gjennomføring, vurdering og kritisk analyse av yrkesspesifikke utdannings- undervisningsog læringsprosesser», og videre som «kritisk analyse og bruk av yrkesfunksjoner/yrkesoppgaver som grunnlag for læring». Definisjonene bygger på en forutsetning om at yrkes- og profesjonskompetanse er strukturert omkring yrkesfunksjoner og yrkesoppgaver, snarere enn omkring vitenskapsdisipliner og skolefag. Utdanningen i både skole og bedrift tar dermed utgangspunkt i yrkesfunksjoner og -oppgaver som teoretiske perspektiver og begrunnelser blir relatert til (Hiim, 2017). Rauner (2007) framhever at å strukturere utdanning rundt arbeidsprosesser er grunnleggende annerledes enn å strukturere den omkring vitenskapsdisipliner og skolefag, og bygger på en annen kunnskapsforståelse.

Definisjonene ovenfor og teori om yrkesdidaktikk i denne studien er inspirert av pragmatiske kunnskapsteorier som legger vekt på at yrkes- og profesjonskunnskap er helhetlig, flerdimensjonal og kommer til uttrykk gjennom handling og begrunnelser for handling (Dreyfus \& Dreyfus, 1988; Hiim, 2013, 2017; Lave \& Wenger, 1991; Schön, 1987, 1995). Kunnskapsbegrepet og kompetansebegrepet blir dermed ganske overlappende. Fra et pragmatisk perspektiv vil det imidlertid stilles kritiske spørsmål til i hvor stor grad yrkeskunnskap eller -kompetanse kan standardiseres og måles, ut fra argumenter om at dette kan bidra til å hindre utvikling av situasjonsavhengig skjønn og ekspertise (Dreyfus \& Dreyfus, 1988; Schön, 1995).

Sett fra et pragmatisk utgangspunkt utvikler elevene grunnleggende begreper i et aktuelt yrke først og fremst gjennom å delta i praktiske yrkeskontekster og utføre profesjonelle oppgaver. Det er derfor vesentlig å kombinere ulike former for skoleopplæring med autentisk arbeidslivspraksis.

Opplæring og praksis i arbeidslivet vil nødvendigvis være preget av produksjonskrav som i noen grad kan stå i motsetning til elevens behov for læring (Billett, 2011; Young, 2004). Skoleopplæring i form av et reflekterende praktikum eller en form for verksted med relevant utstyr hvor elever og lærlinger kan prøve og feile og ha tid til å reflektere og knytte teori til oppgavene, er derfor nødvendig, i tillegg til læring i bedriften (Schön, 1987, 1995).

Veiledning fra en kyndig person er dessuten en forutsetning for å utvikle profesjonskunnskap. Involvering i bedriftens arbeidsfellesskap og muligheter for å utvikle yrkesidentitet skaper 
grunnlag for motivasjon og læring i yrkesutdanningen (Dreyfus \& Dreyfus, 1988; Lave \& Wenger, 1991).

\section{Metode}

Artikkelen bygger på resultater fra en kvalitativ studie (Creswell, 2013) som har undersøkt hvordan lærlinger i mediegrafikerfaget utvikler yrkeskompetanse. I studien ble syv lærlinger i mediegrafikerfaget i utvalgte lærebedrifter fulgt fra lærekontrakten ble inngått og frem til avleggelse av svenneprøve. Utvalget av bedrifter var strategisk for å sikre at bedriftene var ulike og hadde forskjellig produksjon (Patton, 2015). For å belyse problemstillingen og forskningsspørsmålene fra flere aktørers synspunkt har studien også omfattet sju lærere på skoler hvor lærlingene har gjennomført skolegangen. Instruktørene i de aktuelle lærebedriftene og to representanter for opplæringskontor som hadde ansvaret for kontrakten mellom bedriften og lærlingen var også med i undersøkelsen. Studien er godkjent av NSD, og deres retningslinjer for informasjon til deltakerne, samtykke, konfidensialitet, innsamling og arkivering av data er fulgt (Norsk senter for forskningsdata, udatert). For å bidra til anonymisering blir pronomenet «hun» brukt om alle deltakerne.

Datainnsamlingen pågikk over to år, fra mai/juni 2015 til juni 2017, og metodene var observasjoner (Creswell, 2013) i lærebedriftene og semistrukturerte intervjuer (Brinkmann \& Kvale, 2015). Å kombinere disse metodene gjorde det både mulig, gjennom egen tilstedeværelse, å få innblikk i hvordan arbeidet og opplæringen i bedriften faktisk foregikk, og å gjennomføre samtaler i dybden med de ulike aktørene om deres erfaringer med og syn på opplæringen. Vekslingen mellom intervjuer og observasjoner styrket også muligheter til fortløpende å justere fokuset i undersøkelsen ut fra foreløpige analyser av resultater fra hver av metodene.

Det ble valgt en «ikkedeltakende observatørolle» for å forstyrre det daglige arbeidet minst mulig (Creswell, 2013, s. 167). Når det ikke forstyrret arbeidet, ble det under observasjonsdagene likevel gjennomført uformelle samtaler med lærlingen, instruktøren og andre ansatte og stilt spørsmål om arbeidsoppgavene som ble utført. Under observasjonene var fokuset rettet mot hva slags arbeidsoppgaver lærlingen hadde og hvordan opplæringen forgikk. Det ble gjort feltnotater fra observasjonsdagene, og notatene var både deskriptive og reflektive (Creswell, 2013, s. 167). 
Det ble utarbeidet semistrukturerte intervjuguider til samtlige intervjuer (Brinkmann \& Kvale, 2015). Hovedtema i intervjuene var arbeidsoppgaver, innhold og organisering både i skoleopplæringen og i bedriften. Det ble gjort digitale lydopptak av alle intervjuer, og de ble transkribert i sin helhet.

Første del av datainnsamlingen ble gjennomført fra mai til august 2015. Det ble gjort intervjuer med lærlingene og medielærere som hadde undervist dem. Del to ble gjennomført i løpet av det første halvåret av læretiden, mens tredje og siste del ble gjennomført noen måneder før lærlingene skulle avlegge svenneprøve. I del to og tre ble det gjennomført 2-3 dagers observasjoner i lærebedriftene før det ble gjort intervjuer. I disse intervjuene deltok lærlingene og instruktørene i lærebedriftene, samt representantene for opplæringskontoret.

Første del av analysen var å lese igjennom hvert intervju med lærere og lærlinger fra den første datainnsamlingen, notere hva som umiddelbart virket interessant, og skrive memoer til hvert intervju. Neste del var å kode utsagn i henhold til prinsipper for åpen koding (Merriam $\&$ Tisdell, 2016). For å holde oversikt over den store datamengden, ble det kvalitative analyseprogrammet HyperRESEARCH tatt i bruk. Tidlig analyse av data fra den første intervjurunden med lærere og lærlinger gjorde det mulig å følge opp temaer som framsto som vesentlige. Analysen av del 2 og del 3 ble gjort på tilsvarende måte som del 1. Resultater fra nytt materialet førte til at det ble gjort endringer i de opprinnelige kodene og at utsagn i tidligere intervjuer kunne forstås på nye måter (Gibbs, 2007).

Det er samlet inn store mengder data gjennom prosjektet, og i denne artikkelen presenteres resultater som for det første belyser kompetansebehovet i de ulike bedriftene og hva som er sentral kompetanse i mediegrafikerfaget. Her er instruktørenes synspunkter særlig vesentlige. For det andre presenteres resultater som viser lærlingenes, instruktørenes og lærernes erfaringer og synspunkter når det gjelder yrkesrelevansen av skoleopplæringen, sett $\mathrm{i}$ forhold til kompetansebehovene i bedriftene og i mediegrafikerfaget.

I analysen av resultater kom det fram at sentrale elementer når det gjelder kompetansebehov i mediegrafikerfaget kan kategoriseres i samsvar med de tre hovedområdene i læreplanen for VG3 i bedrift: Mediedesign, medieproduksjon, og bedrift, kunde, marked. Denne tredelingen er brukt i presentasjonen av resultatene. Studien viser imidlertid at arbeidsoppgavene og kompetansebehovet for mediegrafikere innen filmproduksjon skiller seg vesentlig fra arbeidsoppgavene til de som arbeider med trykksaker og elektronisk publisering, og disse resultatene blir derfor presentert for seg. Når det gjelder spørsmålet om relevansen av 
skoleopplæringen, viste følgende kategorier seg å være sentrale og blir benyttet i presentasjonen av resultatene: Integrering av teori og praksis, lærernes fagkompetanse, arbeidspraksis i bedrift, produksjonsutstyr og programvare og eksamensordning på VG2.

\section{Resultater}

I det følgende skal vi først presentere resultater som belyser hva som er den viktigste yrkeskompetansen i dagens mediegrafikerfag. Deretter presenteres resultater som belyser yrkesrelevansen av dagens skoleopplæring i møte med yrkesoppgavene i bedriftene. I den avsluttende delen vil vi diskutere hvilken betydning resultatene har i forhold til å oppnå yrkesrelevant skoleopplæring for mediegrafikere i det nye utdanningsprogrammet.

\section{Yrkeskompetanse i mediegrafikerfaget}

\section{MEDIEDESIGN}

Instruktørene var opptatt av at det stilles høye krav til profesjonell yrkesutøvelse for mediegrafikere fordi datateknologien gir stadig flere aktører mulighet til å skape medieprodukter. Instruktør 4 understreket at kompetanse i mediedesign er svært viktig:

Det er mye enklere nå for hvem som helst å lage noe bra, og derfor tenker jeg at en mediegrafiker eller designer må kunne til fingerspissene sin typografi. De må virkelig kunne reglene sine, komposisjonsprinsippene.

I alle bedriftene som jobbet med trykksaker og webdesign ble det lagt stor vekt på at lærlingene utviklet kompetanse innenfor design. Denne kompetansen ses på som varig, noe som er bestandig uansett produksjonsmåte og sluttprodukt. Instruktør 4 sa videre: «Teknologien vil utvikle seg hele tiden, men et komposisjonsprinsipp vil aldri endre seg /.../ Det går nesten innenfor de universelle lovene som finnes, hvis man skal strekke det så langt.» Instruktør 2 understreket også det varige i prinsippene for design:

Det å lære seg grunnkunnskapene om design, estetikk, farger, fonter (dvs. ulike skrifter), linjeavstander - det å bare skjønne konseptene og rammene for god design - for det endrer seg ikke. Denne kompetansen er helt basic /.../ uavhengig av om det er pakningsdesign, internettsider eller hva det måtte være.

Selv om det fins klare retningslinjer for design (Rønning \& Nag, 2017), viser studien at det blir lagt vekt på at lærlingene må utvikle kompetanse i det å se hva som er godt design. 
Instruktør 1 sa: «Ja, rett og slett slik at man ser ting med øyet, da.» På intervjuerens spørsmål til en av lærlingene om hvordan hun brukte teorier om for eksempel leselighet og komposisjonsprinsipper når hun jobbet med utforming av design, svarte lærlingen: «jeg tenker ikke over det, det bare sitter der.» Rett etterpå understreket hun «Men jeg er sikker på at jeg ville hatt et svar hvis noen hadde spurt hvorfor gjør du det.» Utsagnet viser hvordan lærlingen gjennom å arbeide med designprosesser slutter å tenke bevisst over at hun følger teoretiske regler eller retningslinjer for design; «det bare sitter der», eller hun «ser ting med $\varnothing y e t »$. Instruktør 4 understreket at design dreier seg om kompleks kompetanse det tar lang tid å lære:

Det å lære seg design har en god del med psykologi å gjøre, å skjønne hva det er folk responderer på /.../ og det er ikke gjort på fem minutter. Du skal jobbe med det en stund for å skjønne det og se sammenhengen.

Instruktørene var tydelige på at god kompetanse i design er viktig for å være rustet til omstillinger og videre kompetanseutvikling. Instruktør 2 sa: «Har man med seg designkompetansen /.../ så har man grunnlaget for å utvikle seg videre, man sitter med en viss trygghet.»

Resultatene viser samlet sett svært tydelig at kompetanse i design - utforming og sammensetning av bilder, tekst og designelementer, og valg av farger, former og skrift i trykksaker og i elektroniske publikasjoner - er en grunnleggende forutsetning for profesjonell utøvelse og utvikling i mediegrafikerfaget, og at det her stilles store krav til lærlingene.

\section{MEDIEPRODUKSJON}

Det ble understreket at kompetanse i medieproduksjon, dvs. bruk av verktøy, teknologi og utstyr, og kvalitetssikring av produksjonen, også er svært viktig for mediegrafikeren.

Instruktør 4 sa følgende: «Samtidig må vi ikke glemme /.../ ferdiggjøring og tilrettelegging av dokumenter og det å klargjøre dem til de ulike plattformene.» Det betyr at mediegrafikeren skal ha kompetanse i å klargjøre for eksempel bildefiler i tråd med ulike tekniske krav til trykksaker og nettpublisering.

God kompetanse i medieproduksjon blir sett på som en forutsetning for å være kreativ og kunne utforme det designet som mediegrafikeren $\emptyset$ nsker. Instruktør 2 sa: 
Det blir raskere og enklere å være kreativ med en strukturert forståelse for hvordan du skal jobbe /.../ Det er ikke verktøyene som skal legge føringer for hvordan et resultat blir. Det er kun ens egen kreative kunnskap og forståelse.

Kompetanse i design og produksjon blir sett på som ulike sider ved helhetlig yrkeskompetanse. Instruktør 2 understreket at «for å bli en god mediegrafiker /.../ så trenger du alle elementene /.../ kunne designe, kunne programvaren.» Kompetanse i design og produksjon blir ansett for å stå i et gjensidig avhengighetsforhold til hverandre. Man må ha designkompetanse for å lage medieproduksjoner som blir vurdert som profesjonelle. Mediegrafikeren må også ha god teknisk kompetanse, slik at manglende kompetanse i programvaren ikke fører til at hun ikke kan utføre det designet hun ønsker. Lærling 2 uttrykte det slik: «Alt det tekniske jeg lærer gjør det lettere å være kreativ senere, å kunne løse ting på forskjellige måter.»

For noen av bedriftene ble lærlingene raskt en ressurs innen medieproduksjon. I noen tilfeller hadde lærlingene kompetanse som ingen andre i bedriften hadde. Instruktør 2 sa: «Jeg har vært nesten utelukkende positivt overraska over at de kan såpass mye i de forskjellige programmene /.../ så de har lært meg en del ting fordi de har nyere utdanning.» Noen av lærlingene hadde fått opplæring på skolen, mens andre hadde utviklet denne kompetansen på fritiden fordi de brukte aktuelle dataprogrammer som fritidssyssel. Flere hadde lært gjennom å delta på kurs i aktuell programvare på opplæringskontoret. Lærling 4 fortalte at noen av kollegaene hadde begynt å spørre henne om hvordan man går fram i den tekniske produksjonen: «Alle her er veldig oppdatert, men det hender jo man spør hverandre. /.../ Da er det faktisk noen som kommer og spør meg (ler).»

\section{BEDRIFT, KUNDE, MARKED}

Innen dette hovedområdet viser studien at det særlig er kundebehandling som står i fokus. Instruktør 1 uttrykte det slik: «En viktig del av yrkesutøvelsen er å sende korrekturer og ha kontakt med kunder, å overholde frister, ja, rett og slett kundebehandling.» På intervjuerens direkte spørsmål: «Hva er det viktigste lærlingen må lære seg nå i begynnelsen?», svarte instruktør 2: «Noe av det viktigste er faktisk å stille spørsmål, slik at hun forstår eksakt hva kunden ønsker.» Hun forklarte videre at enkelte kunder ikke er gode til å ordlegge seg og gir beskjeder som kan misforstås. Lærlingen måtte derfor «tørre å spørre og ikke være redd når man ikke forstår. Man må finne ut av ting før man starter på en oppgave.» 
Studien viser at det er viktig for lærlingene å lære å planlegge slik at de forskjellige jobbene blir ferdig til tidsfristen. Instruktør 1 sa: «Noe av det viktigste er å få sendt ting i tide til kunden, sånn at vi rekker å få det til trykk innen fristen.» Lærling 1 fortalte at det å ta ansvar for at produksjonen ble ferdig innen fristen var blitt en naturlig del av jobben:

Hvis det er noe som hadde frist eller deadline er det kjempeviktig. Man kan ikke bare gå på fredagen hvis man har noe som hadde frist på fredagen fra kunden. Jeg kan ikke dra hjem og legge meg om kvelden da, for da får jeg ikke sove. Hadde man vært sånn at man gikk, og ikke hadde noe særlig interesse for å forsikre seg om at ting er i orden, så passer man kanskje ikke inn her.

Denne og liknende uttalelser viser at holdninger til å gjøre en god jobb blir oppfattet som en forutsetning for å fungere i bedriften.

\section{FILMPRODUKSJON}

Filmproduksjon skiller seg fra resten av mediegrafikerfeltet når det gjelder produksjonsoppgaver og -utstyr, og dreier seg om redigering, klipping og logging av filmklipp, rigging av filmutstyr, og praktisk og teknisk assistanse under filmproduksjon.

Lærling 3 i filmproduksjonsbedriften begynte opplæringen med å se på hva andre gjorde. Hun forklarte: «Du får litt opplæring underveis. Du får være med å se hvordan f.eks. logging (å legge inn informasjon på filmklipp) blir gjort, hvordan klippeassistentene jobber og sånne ting.» Instruktør 3 fortalte at lærlingen fikk mulighet til å øve seg i redigeringsprogrammet ved å «ta frem gammelt materiale fra reklamefilmer, og så klippe sine versjoner.» Lærlingene i de andre bedriftene kom fortere i gang med å ta selvstendig del i den tekniske medieproduksjonen, noe som har sammenheng med at det i filmbedriften er snakk om mer omfattende, sammensatte og dyrere produksjoner.

Instruktør 3 fortalte videre at lærlingen «bidro med vanlige produksjonsassistent-tjenester på filmsettet». Lærling 3 forklarte at som produksjonsassistent hadde hun

... gjort alt fra å lage kaffe til å sette sammen lunsj og smøre mat. Og så har jeg drevet med rigging av utstyr, satt opp eller hjulpet de forskjellige avdelingene med alt egentlig. Rigging av utstyr, sette opp lamper, flytte kamera og sånne ting.

Hun forklarte hva slags kompetanse som er viktig: 
«En produksjonsassistent sin jobb er å aldri stå i veien, og alltid være beredt på at noen kan trenge hjelp. En flink produksjonsassistent ser hvem som trenger hjelp før de spør om det /.../, og man skal alltid være klar.»

Instruktøren la vekt på at det under opptak ikke er rom for å gjøre feil: «For det får ofte veldige store økonomiske konsekvenser /.../ Så jeg sier alltid at er du usikker, så spør heller ti ganger enn å gå og tro og så ta en feil beslutning.»

Resultatene viser at produksjonstype, utstyr og oppgaver som lærling i filmproduksjon er ganske forskjellig fra tradisjonelle mediegrafikeroppgaver.

\section{OPPSUMMERING}

Resultatene viser samlet sett at mediegrafikere må ha en høy, helhetlig kompetanse som omfatter design og produksjon av elektroniske og trykte medier, kommunikasjon med kunder og evne til selvstendig ansvar og utvikling i arbeidet. Spørsmålet er hvor relevant dagens skoleopplæring har vært for å utvikle denne kompetansen.

\section{Yrkesrelevansen av skoleopplæringen}

\section{RELEVANS GJENNOM Å INTEGRERE TEORI OG PRAKSIS I PRODUKSJONER OG OPPDRAG}

Studien viser at opplæringen i skole har vært organisert rundt helhetlige medieproduksjoner, hvor yrkesteori i stor grad har vært integrert i elevenes praktiske arbeid. Lærer 5 beskrev det slik:

Jeg har litt tavleundervisning, men jeg legger det inn mellom øvelser der det er relevant. /. . / Når elevene har for eksempel et journalistikkprosjekt, /.../ ser du at nå er vi kommet til det stedet hvor det er naturlig å undervise litt om etikken. Så tar vi en felles $\varnothing \mathrm{kt}$ på det, og deretter fortsetter de med opplegget.

Lærer 4 sa: «Jeg synes jeg underviser veldig lite i teori, jeg bruker mye tid på veiledning. Vi har jo teori, men vi prøver å anvende det veldig praktisk hele veien.» Teoriøktene ble lagt der de passet inn i elevenes praktiske arbeid med medieproduksjonene. Elevene lærte ifølge lærerne teorien vel så mye gjennom veiledning i konkrete situasjoner de sto oppe i som gjennom tradisjonelle forelesninger. På flere av skolene var det ikke satt opp faste timer for de tre programfagene i læreplanen verken på VG 1 eller VG 2. Som lærer 7 sa: «Selv om vi har medieproduksjon, mediedesign og mediekommunikasjon som tre mediefag, så jobber vi tverrfaglig med alt samtidig.» 
På noen av skolene hadde elevene lagd medieproduksjoner som var blitt brukt internt på skolen eller produksjoner for eksterne oppdragsgivere. Lærling 2 fortalte: «Vi har hatt en del oppdrag for danselinja og for åpen skole.» Lærling 6 fortalte at de hadde hatt samarbeid med en offentlig etat om en holdningskampanje:

Da kom noen fra oppdragsgiver og fortalte om det, og så lagde alle ideer, og vi pitcha for oppdragsgiver. Hvis ideene virka bra så dro vi ut og filma. Så fulgte de oss hele veien til vi til slutt leverte filmer. Noen av filmene ble trukket ut til å vises på kino.

Lærlingen forklarte det spesielle med et slikt oppdrag: «Det var jo spennende, for da visste man at man lagde et produkt som faktisk skulle vises, bli brukt ute i verden.» Oppdrag for eksterne kunder bidro ifølge lærer 5 til at elevene forsto «at det er for virkeligheten de gjør det».

Av lærlingene i denne undersøkelsen var det tre stykker som hadde fått mulighet til å jobbe med reelle oppdrag i løpet av skoleopplæringen. Lærlingene ga uttrykk for at dette ga stort læringsutbytte og lærerne på disse skolene anså dette som viktig for yrkesrelevansen av opplæringen. Det kom tydelig frem at lærerne brukte ressurser på å skaffe eksterne kunder og hadde opparbeidet et nettverk. Som lærer 2 sa: «Vi har mer enn nok av forespørsler». Oppdragene på disse tre skolene var dessuten organisert slik at de ga muligheter for å arbeide med oppgaver som var relevante for det aktuelle yrket, i dette tilfellet mediegrafiker. Andre skoler hadde ikke eksterne oppdrag. Lærling 7, som ikke hadde hatt oppdrag fra eksterne kunder fortalte om medieproduksjonene på denne måten: «Det var å fantasere om at det var en kunde som skulle ha det og det, men det var jo bare til lærerne.»

Resultatene viser at de fleste lærerne la vekt på å integrere fag og teoretisk og praktisk kunnskap knyttet til ulike typer prosjekter og produksjoner, men at det varierte både i hvor stor grad produksjonene var knyttet til eksterne oppdrag og hvorvidt de var relatert til elevenes yrkesvalg som mediegrafikere.

Instruktørenes var imidlertid opptatt av at produksjonsoppgavene som elevene jobbet med i skoleopplæringen var knyttet til det spesifikke yrket de skulle utdanne seg til. De mente at elevene i for liten grad hadde fått anledning til å spesialisere seg og lære seg det grunnleggende i mediegrafikeryrket. Instruktør 1 sa: «På skolen så gjør man jo veldig mye forskjellig. Det er mye radio, web, TV, du har alt mulig, og en liten del av det er litt grafisk 
arbeid.» Også instruktør 6 sa: «Det er fort at det kan bli for generelt. Nå er det ikke sikkert de har hatt typografi en gang.»

\section{L/ERERNES FAGKOMPETANSE}

Både instruktører og lærlinger i undersøkelsen framhevet at lærerens yrkeskompetanse var en utfordring i utdanningsprogrammet, og at det skapte problemer hvis ingen av lærerne hadde kompetanse som mediegrafiker. Instruktør 6 sa: «Det er veldig forskjell egentlig på hva elevene lærer, og det kommer i stor grad an på læreren.» Mens noen av lærlingene opplevde at de hadde lærere som hadde yrkesbakgrunn fra det yrket de ville utdanne seg til, var det andre som hadde erfart at ingen av lærerne hadde fagbrev eller spesifikke kunnskaper i mediegrafikeryrket, og mente at dette bidro til at de var dårlig kvalifisert til å bli lærlinger (Aakernes, 2018).

\section{ARBEIDSPRAKSIS I BEDRIFT}

Av lærlingene i denne studien var det kun to som hadde hatt utplassering i bedrift i løpet av skoletiden. Lærling 7 sa:

Jeg lærte mer der første dagen enn jeg hadde lært to år på skolen. Jeg fant fort ut at det å faktisk gjøre noe /.../ ute i bedrift, sånn at du vet at du gjør det riktig, det er veldig viktig.

Denne lærlingen skaffet utplasseringsplassen sin selv ved å dra til bedriften og presentere seg. Hun sa at utplasseringen hadde vært avgjørende for at hun ble lærling: «Jeg tror ikke jeg hadde vært mentalt klar for det hvis jeg ikke hadde hatt den praksisplassen. For da hadde jeg ikke visst hva det (læreplass) hadde innebært.» Den andre lærlingen mente også at utplassering i bedrift hadde vært avgjørende for å bli mediegrafiker (Aakernes, 2018).

Det har ifølge både lærerne og instruktørene blitt regnet som vanskelig å få til utplassering for MK-elevene. En av årsakene har vært en oppfatning av at mange av elevene i programmet ikke har ønsket en fremtidig jobb i mediebransjen. Lærling 5 sa det slik: «Det var veldig mange som gikk media bare for å ha to morsomme år på skolen.» En av representantene fra opplæringskontoret framhevet erfaringer med elever som manglet interesse for fremtidig jobb i bransjen: «Så sier ganske mange av bedriftene at dette gidder vi ikke, for elevene var jo egentlig ikke interessert.» En annen årsak til lite utviklet samarbeid mellom skoler og bedrifter er at elevene i videregående skole må konkurrere om praksisplasser med studenter fra medieutdanninger på høgskolenivå (Aakernes, 2018). 
Selv om representantene fra opplæringskontoret mente det var vanskelig å organisere utplassering som en allmenn ordning, så ble det likevel nevnt eksempler på elever som har tatt et personlig initiativ:

Det var en elev fra VG1 som tok kontakt og lurte på om hun skulle bli lærling etter VG2. Hun lurte på om vi kunne hjelpe henne med utplassering. /.../ Og det er klart, da gjør vi mye for henne.

Representanten fortalte at denne eleven hadde fått læreplass hos et navngitt firma. På opplæringskontoret var det en klar oppfatning av at kontakt om utplassering er en vei til læreplass. Flere av instruktørene ga også uttrykk for at de generelt sett er positive til å utvikle et nærmere samarbeid med skoler om arbeidspraksis (Aakernes, 2018).

Lærerne ga på sin side uttrykk for ulike holdninger til samarbeid med bedrifter. Noen sa at de hadde lite eller ikke noe utplassering i det hele tatt fordi det var vanskelig å få til. Andre trakk frem yrkesfaglig fordypning og utplassering som det de fikk best tilbakemelding på. Lærer 3 sa: «Det funker veldig bra, vi forsøker å få utplasseringer så sant det går.» Det er imidlertid avgjørende for elevenes opplevelse av yrkesrelevans at det er samsvar mellom den enkeltes yrkesplaner og arbeidsoppgavene i den aktuelle bedriften. Lærling 2, som hadde tilbud om utplassering, forklarte hvorfor hun hadde valgt det bort: «Utplassering var bare mulig i avis og journalistikk og sånne ting som ikke interesserer meg.»

Studien viser også at informasjonen om lærlingeordningen har vært svært mangelfull på de fleste skolene. Flere av lærlingene trakk frem at det var få som ville bli lærlinger, og regnet med at det var årsaken til lite informasjon. Lærling 6 forklarte: «De liksom forventer /.../ at man skal studere videre.»

Lærling 1, som først begynte i lære etter VG3 medier og kommunikasjon i skole sa det på denne måten:

De gikk liksom ikke i dybden på hva man gjør når man er lærling. Jeg tenker at hvis jeg hadde oppdaga dette her før, at jeg kunne bli mediegrafiker, og hva jeg jobber med, så hadde jeg kanskje hatt interesse tidligere.

Resultatene tyder på at samarbeidet mellom skoler og bedrifter har vært svakt $\mathrm{i}$ utdanningsprogrammet. Flere av instruktørene og enkelte lærere mente imidlertid at det er et uutnyttet, men reelt potensial for et tettere samarbeid mellom skoler, opplæringskontor og bedrifter. 


\section{PRODUKSJONSUTSTYR OG PROGRAMVARE}

Skoleopplæringen har i ganske stor grad gitt elevene mulighet til å lære seg å bruke det utstyret og den aktuelle programvaren de møter i arbeidslivet. Instruktørene var av den oppfatning at det var god standard på utstyret. Også flere av lærlingene mente at de hadde fått opplæringen på relevant utstyr: «Vi hadde Mac' er med samme programvare, så det er stort sett det samme nå (i bedriften) som det var på skolen» (Lærling 5). «Det var kjempegodt utvalg på skolen av videokameraer, lydopptakere, mikrofoner, vanlige speilreflekskameraer» (Lærling 7).

Enkelte lærlinger syntes imidlertid det fungerte dårlig med små bærbare maskiner på skolen. Lærling 1 forklarte at det ble mer oversiktlig å utforme medieproduksjoner på de store skjermene på arbeidsplassen: «Det blir mye mer ordentlig, og man har plass til å lagre ting.»

En svakhet ved den tekniske opplæringen på skolene har også vært at elevene ikke har fått mulighet til å få trykksakene de har utformet ferdig trykt. Instruktør 4 sa: «De vet gjerne hvordan de skal printe ut og få noe til å se bra ut på den printeren som de hadde på skolen, men aner ikke hvordan de faktisk skal klargjøre en PDF til trykk.» På en av skolene hadde de heller ikke mulighet til å skrive ut trykksaker på printer, noe som gjorde det vanskelig for elevene å få et godt inntrykk av hvordan det ferdige resultatet blir når det gjelder for eksempel valg av skriftstørrelse. Lærer 6 forklarte «Vi skal jo utdanne folk som skal kunne sette tekst med riktig linjeavstand, og lesbarheten skal ivaretas /.../ i et magasinoppslag for eksempel /.../ på skjermen ser jo alt bra ut, men ser du at den teksten din er på 48 pkt!» Læreren beskrev manglende trykkemuligheter som «en veldig stor svakhet» og sa videre: «Du må se ting på trykk før du kan mene noe.»

Selv om det var noen utfordringer knyttet til produksjonsutstyr og programvare, så framhevet instruktører og lærlinger at likheter i utstyr mellom skolen og bedriftene ga muligheter til å gjennomføre liknende oppgaver på skolen som i de ulike aktuelle bedriftene, men at mulighetene kunne utnyttes bedre.

\section{EKSAMENSORDNINGEN PÅ VG 2}

På en del skoler/fylkeskommuner er tverrfaglig eksamen på VG2 MK blitt organisert etter prinsippet om at elevene må trekke hvilket yrke de skal opp i til eksamen (Bødtker-Lund et al., 2017). Enkelte av lærerne framhevet at dette hindret dem i å tilrettelegge opplæringen slik at elevene fikk spesialisere seg i valgt yrke, og skapte problemer for elevene dersom de likevel hadde fått anledning til å spesialisere seg. Lærer 2 fortalte om en elev som skulle bli 
lærling: «Hun trakk noe helt annet enn det hun skal ut i lære som. Du får litt vondt i magen da altså, og jeg synes eksamensformen er grusom.» Lærer 4, som arbeidet ved en skole hvor de ikke gjennomførte eksamen på denne måten, sa: «Det er jo fryktelig å plutselig få eksamensoppgave i lyd hvis du har spesialisert deg i film, eller enda verre, grafisk.»

På enkelte skoler har eksamen vært organisert som generelle case-oppgaver som elevene kan løse ut fra hvilket yrke de har ønsket å spesialisere seg i. Lærer 5 fortalte: «Så da velger de enten journalistikk eller så kan de velge reklame eller holdningskampanje /.../ og da velger de også om de vil lage plakater eller reklamefilm eller sånne ting.» Studien tyder på at det var store forskjeller i hvordan eksamensforskrifter ble tolket og at dette fikk konsekvenser for i hvilken grad lærerne lot elevene få mulighet til spesialisering (Aakernes, 2018).

\section{Yrkesrelevant skoleopplæring for mediegrafikere - utfordringer og muligheter}

I diskusjonen om yrkesrelevant skoleopplæring for mediegrafikere vil vi først drøfte resultater som viser utfordringer om relevans i dagens opplæring. Deretter drøfter vi hva som må til for å oppnå en yrkesrelevant utdanning i det nye utdanningsprogrammet IKT og medieproduksjon.

Studien viser at det stilles store krav til at lærlinger og mediegrafikere utvikler en høy, helhetlig kompetanse i design og produksjon av elektroniske og trykte medier, og i å kommunisere godt med kunder om medieproduksjonene. Resultatene viser dessuten at produksjonstype, utstyr og oppgaver i filmproduksjon er forskjellig fra mediegrafikerfaget. Et eget fagbrevområde på VG 3 slik det nå legges opp til kan bidra til å utvikle dette feltet som et eget yrke (Utdanningsdirektoratet, 2018).

Både instruktører og lærlinger understreket at kompetanse i design og produksjon er gjensidig avhengig av hverandre i mediegrafikerens arbeid og læres i en helhet som også omfatter kommunikasjon med kunder. Deres oppfatning av yrkeskompetanse som helhetlig er i samsvar med definisjoner og teorier om et helhetlig, flerdimensjonalt kunnskaps- og kompetansebegrep (Koenen et al., 2015) og med at yrkeskompetanse er strukturert omkring yrkesfunksjoner og -oppgaver (Dreyfus \& Dreyfus, 1988; Hiim, 2017; Schön, 1995). Spørsmålet er hvordan den skolebaserte delen av opplæringen har bidratt til at elever og 
lærlinger utvikler den mediegrafikerkompetansen som blir beskrevet. Her avdekker resultatene betydelige utfordringer, men også muligheter.

Utdanningen har i stor grad vært organisert omkring helhetlige medieproduksjoner hvor teori og ulike programfag har vært integrert i praktiske arbeidsoppgaver, noe som er et viktig prinsipp i kompetansebaserte og pragmatisk inspirerte tilnærminger til yrkesutdanning (Heusdens et al., 2016). Problemet er imidlertid at de praktiske oppgavene i mange tilfeller ikke i tilstrekkelig grad har vært relevante for yrket eleven ønsket å utdanne seg til. Et journalistoppdrag for radio er f.eks. ikke særlig yrkesrelevant for en elev som vil bli mediegrafiker. Det er ikke tilstrekkelig å gjennomføre praktiske oppgaver i en yrkesutdanning - oppgavene må være relevante og sentrale for det aktuelle yrket (Hiim, 2017; Koenen et al., 2015; Aakernes, 2018). Problemene har sammenheng med bredden i utdanningsprogrammet og med at læreplanene kan tolkes slik at elevene må lære litt om hvert av yrkene i programmet (Bødtker-Lund et al., 2017; Hiim, 2013).

Samarbeid mellom skole og arbeidsliv og muligheter for praksis i bedrift ser på grunnlag av resultatene ut til å være særlig svakt i program for medier og kommunikasjon sammenliknet med andre utdanningsprogram (Olsen \& Reegård, 2013). Noe av forklaringen er sannsynligvis at dette programmet også har forberedt til høgskoleutdanning. Uten kontakt med bedrifter blir det vanskelig å forankre innholdet i skoleutdanningen i autentiske arbeidsoppgaver, noe forskere og teoretikere innen yrkesutdanning er blitt stadig mer opptatt av (Cremers et al., 2016; Wahlgren \& Aarkrog, 2012; Zitter et al., 2016). Resultatene viser at lærerne er positivt innstilt til arbeidslivspraksis, men de har opplevd at det har vært vanskelig å organisere. De få lærlingene som har hatt praksis i mediegrafikerbedrifter i skoledelen rapporterte om stort utbytte, mens andre følte seg dårligere forberedt til læretiden.

Produksjonsutstyret på skolene var ifølge studien relativt rikholdig og har gitt gode muligheter til å gi elevene oppgaver innen ønsket spesialiseringsfelt, uten at disse i tilstrekkelig grad har blitt utnyttet. Resultatene tyder på at mangel på yrkesdifferensiering kan skyldes manglende lærerkompetanse innen de aktuelle fagbrevområdene og eksamensordninger som vanskeliggjør spesialisering, noe som samsvarer med resultater fra annen forskning på yrkesutdanningen (Bødtker-Lund et al., 2017; Hiim, 2013).

Studien viser at en elev som vil bli mediegrafiker kan risikere å få liten anledning til å arbeide med oppgaver knyttet til yrket i skoledelen, ikke få veiledning fra noen med kompetanse i yrket, og i tillegg trekke en eksamensoppgave som forutsetter kompetanse i et annet 
yrkesområde. På den annen side viser resultatene at lærlingene i noen tilfeller har opplevd både å få oppgaver på skolen som er tilpasset yrket, faglig kvalifisert veiledning i en form for reflekterende praktikum, og yrkesrelevant eksamen.

Resultatene bekrefter samlet sett at dagens læreplaner i utdanningsprogram for medier og kommunikasjon gir rom for motstridende tolkninger (Bødtker-Lund et al., 2017; Hiim, 2013). Hovedutfordringen er at skoledelen er lite spesialisert og at sammenhengen mellom innhold i skole og bedrift er for svak. Dette kan antakelig være en viktig grunn til at lærlinger på MK er de som har vært minst fornøyd med skoleopplæringen som forberedelse til læretiden (Utdanningsdirektoratet, 2016b). Mye forskning på yrkesutdanning peker mot viktigheten av å utvikle modeller som overskrider grenser mellom skole og arbeidsliv (Dreyfus \& Dreyfus, 1988; Koenen et al., 2015; Schön, 1995; Zitter et al., 2016).

Resultater fra studien bekrefter at føringene i den nye reformen om større muligheter for å spesialisere seg i valgt yrke er et skritt i riktig retning (Kunnskapsdepartementet, 2018).

Norge er imidlertid et langstrakt land, og det er vanskelig å organisere spesialiserte utdanningstilbud over alt. Også etter reformen vil utdanningsprogrammene i yrkesfag være relativt brede på grunn av praktiske og organisatoriske hensyn.

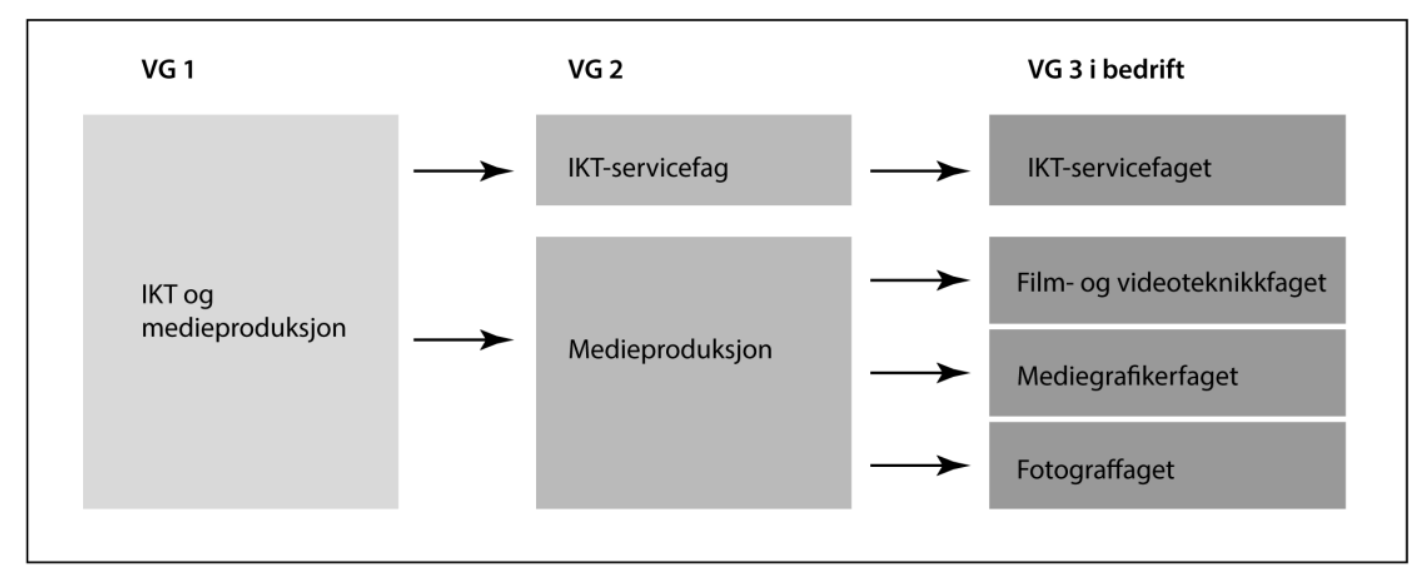

\section{Figur 1}

Nytt utdanningsprogram for IKT og medieproduksjon fra skoleåret 2020/2021.

Figur 1 viser at elvene etter VG 1 i det nye utdanningsprogrammet for IKT og medieproduksjon kan velge enten VG 2 IKT-servicefag eller VG 2 medieproduksjon. Det er planlagt at VG 2 IKT-servicefag leder frem til VG 3 opplæring i bedrift i ett fagbrevområde, IKT-servicefag. Etter VG 2 medieproduksjon kan elevene velge mellom VG 3 opplæring i bedrift i tre fagbrevområder; film- og videoteknikkfaget, mediegrafikerfaget og fotograffaget. 
I den nye utdanningen av mediegrafikere er det viktig å møte utfordringene som er diskutert ovenfor. Læreplanene for VG 3 skal beskrive den kompetansen som er nødvendig for å utføre yrket som henholdsvis mediegrafiker, fotograf, film- og videotekniker og IKT servicetekniker, og planen for VG 3 mediegrafikere kan bli litt mer spesialisert enn tidligere. Læreplanen for VG2 medieproduksjon er imidlertid felles for tre lærefag og må dermed bygge på analyse av hva slags kompetanse disse har felles. I planen for VG1 må i tillegg yrkeskompetansen for IKT servicefag inkluderes. Det er en fare for at planene for både VG 1 og VG 2 blir så generelle at de ikke i tilstrekkelig grad styrker mulighetene for spesialisering.

En mulig løsning kan være å supplere generelle, felles læringsutbyttebeskrivelser med kompetansebeskrivelser på aktuelt nivå for hvert enkelt av yrkene som inngår på VG 1 og VG2. Dette kan styrke muligheter for å differensiere opplæringen slik at den er tilpasset elevenes ønske om spesialisering som f.eks. mediegrafikere, noe som ifølge studien har stor betydning for elevenes motivasjon, forberedelse til læretiden og muligheter for å få læreplass. Det vil også være i samsvar med generelle føringer om spesialisering (Kunnskapsdepartementet, 2018).

Både resultater fra denne studien, annen forskning og teori på feltet peker mot at yrkeskompetanse utgjør en helhet som ikke uten videre bør splittes opp i separate skolefag (Dreyfus \& Dreyfus, 1988; Hiim, 2017; Koenen et al., 2015). Det kan være hensiktsmessig med ett felles programfag både på VG 1 og VG 2.

For å styrke samarbeidet mellom skoler og bedrifter og legge til rette for at elevene får praksis i bedrift kan faget «yrkesfaglig fordypning» heller hete f.eks. «arbeidslivspraksis». Det kan med fordel presiseres ytterligere at faget så langt overhodet mulig skal gjennomføres i relevant bedrift, og at skolen og bedriften bør samarbeide om innhold og oppgaver i opplæringen for øvrig for å sikre relevans og sammenheng mellom de ulike læringsarenaene. Resultater fra studien tyder i samsvar med annen forskning på at retningslinjer for krav til bred kompetanse i lærerteamene bør spesifiseres, slik at elever som vil bli mediegrafikere og elever med andre spesialiseringsønsker så langt mulig får veiledere og lærere med kompetanse i yrket (Bødtker-Lund et al., 2017; Hiim, 2013). Det er også viktig med retningslinjer for at eventuell mangel på breddekompetanse i lærerteamet bør kompenseres gjennom kontakt med opplæringskontor, bedrifter og instruktører innen de aktuelle fagbrevområdene. 


\section{Konklusjon}

Studien viser at mediegrafikere må ha høy, helhetlig kompetanse i design og utvikling av medieproduksjoner for skjerm og trykk, og i kundebehandling. Skoledelen av dagens utdanning har i for liten grad gitt elever som vil bli mediegrafikere anledning til å begynne utviklingen av slik kompetanse og har derfor ikke forberedt godt nok til læretiden. I det nye utdanningsprogrammet for IKT og medieproduksjon må det utarbeides læreplaner og retningslinjer som på alle nivå tar utgangspunkt i analyser av kompetansebehovene i yrkene som inngår, og gir eksplisitte føringer om at elevene skal ha muligheter for å spesialisere seg som mediegrafikere eller i andre yrker allerede fra VG1. Det må også gis klare føringer for samarbeid mellom skoler og bedrifter om arbeidslivspraksis og utdanningsinnhold innen mediegrafikeryrket og andre yrker.

\section{Referanser}

Amdam, S. (2016a). The dangers of having fun - doing production work in school. I O. Erstad, K. Kumpulainen, Å. Mäkitalo, K. C. Schrøder, P. Pruulmann-Vengerfeldt \& T. Jóhannsdóttir (Red.), Learning across Contexts in the Knowledge Society (s. 85108). Rotterdam: SensePublishers. https://link.springer.com/content/pdf/10.1007\%2F978-94-6300-414-5.pdf

Amdam, S. (2016b). Media Education Goes Professional? Media Teachers' Self-Image, Positioning and Educational Focus. Nordicom Review, 37(2), 81-95. https://doi.org/10.1515/nor-2016-0019

Billett, S. (2011). Vocational Education: Purposes, Traditions and Prospects. Dordrecht: Springer.

Brinkmann, S. \& Kvale, S. (2015). InterViews: Learning the craft of qualitative research interviewing (3. utg.). Thousand Oaks, Calif: Sage.

Bødtker-Lund, D., Hansen, K. H., Haaland, G. \& Vagle, I. (2017). Endringsbehov i norsk yrkesopplæring? - Elevers, lærlingers og yrkesfaglæreres erfaringer med yrkesopplæring i Vg1. Scandinavian Journal of Vocations in Development, 2, 1-33. https://doi.org/10.7577/sjvd.2577 
Cremers, P. H. M., Wals, A. E. J., Wesselink, R. \& Mulder, M. (2016). Design principles for hybrid learning configurations at the interface between school and workplace. Learning Environments Research, 19, 309-334. https://doi.org/10.1007/s10984-016$\underline{9209-6}$

Creswell, J. W. (2013). Qualitative inquiry \& research design: Choosing among five approaches (3. utg.). Los Angeles: Sage.

Dahlback, J., Hansen, K., Haaland, G. \& Sylte, A. L. (2011). Yrkesdidaktisk kunnskapsutvikling og implementering av nye læreplaner (KIP). Lillestrøm: Høgskolen i Akershus. Hentet fra https://skriftserien.hioa.no/index.php/skriftserien/article/view/83

Dahlback, J., Hansen, K., Haaland, G. \& Vagle, I. (2015). Yrkesfaglærerens kompetanse i framtidens skole. I K. H. Hansen, T. L. Hoel \& G. Haaland (Red.), Tett på yrkesopplæring: Yrkesrelevant, tilpasset og samfunnstjenlig? (s. 89-108). Bergen: Fagbokforlaget.

Dreyfus, H. L. \& Dreyfus, S. E. (1988). Mind over machine: The power of human intuition and expertise in the era of the computer. New York: Free Press.

Erstad, O., Gilje, Ø. \& de Lange, T. (2007a). Morgendagensmedieprodusenter. Oslo: Universitetet i Oslo. Hentet fra http://webcache.googleusercontent.com/search?q=cache:OoZVM96NpBgJ:www.ituar kiv.no/filearchive/morgendagens_medieprodusenter.pdf $+\& \mathrm{~cd}=1 \& \mathrm{hl}=\mathrm{no} \& \mathrm{ct}=\mathrm{clnk} \& \mathrm{gl}$ =no\&client=safari

Erstad, O., Gilje, Ø. \& de Lange, T. (2007b). Re-Mixing Multimodal Resources: Multiliteracies and Digital Production in Norwegian Media Education. Learning, Media and Technology, 32(2), 183-198. https://doi.org/10.1080/17439880701343394

Frøseth, M. W., Hovdhaugen, E., Høst, H. \& Vibe, N. (2008). Tilbudsstruktur og gjennomføring i videregående opplæring. Delrapport I. Evaluering av Kunnskapsløftet. Oslo: NIFU STEP Hentet fra https://www.udir.no/globalassets/filer/tall-ogforskning/rapporter/evak1/5/nifu_tilbudstruktur.pdf 
Gessler, M. (2017). The Lack of Collaboration between Companies and Schools in the German Dual Apprenticeship System: Historical Background and Recent Data. International Journal for Research in Vocational Education and Training, 4(2), 164195. https://doi.org/10.13152/IJRVET.4.2.4

Gibbs, G. (2007). Analyzing qualitative data. London: SAGE.

Hansen, K. H. (2017). Hva er yrkesdidaktikk i dagens yrkesopplæring i skole? [What is vocational curriculum in todays school-based VET]. Scandinavian Journal of Vocations in Development, 2, 1-25. https://doi.org/10.7577/sjvd.2134

Heusdens, W. T., Bakker, A., Baartman, L. K. J. \& De Bruijn, E. (2016). Contextualising Vocational Knowledge: A Theoretical Framework and Illustrations from Culinary Education. Vocations and Learning, 9, 151-165. https://doi.org/10.1007/s12186-0159145-0

Hiim, H. (2013). Praksisbasert yrkesutdanning. Oslo: Gyldendal akademisk.

Hiim, H. (2015). Kvalitet i yrkesutdanningen: Resultater fra et aksjonsforskningsprosjekt om yrkesforankring av innholdet i yrkesutdanningen [The quality of curriculum in VET: Results from an action research project on content and structure in VET]. Norsk pedagogisk tidsskrift, 99(2), 136-148. Hentet fra https://www.idunn.no/npt/2015/02/kvalitet_i_yrkesutdanningen__resultater_fra_et_aksjonsfors

Hiim, H. (2017). Ensuring Curriculum Relevance in Vocational Education and Training: Epistemological Perspectives in a Curriculum Research Project. International Journal for Research in Vocational Education and Training, 4(1), 1-19. https://doi.org/10.13152/IJRVET.4.1.1

Hiim, H. \& Hippe, E. (2001). Å utdanne profesjonelle yrkesutøvere. Oslo: Gyldendal akademisk.

Kairisto-Mertanen, L., Räsänen, M., Lehtonen, J. \& Lappalainen, H. (2012). Innovation pedagogy - learning through active multidisciplinary methods. Revista de Docencia Universitaria, 10(1), 67-86. Hentet fra https://dialnet.unirioja.es/descarga/articulo/4020166.pdf 
Koenen, A.-K., Dochy, F. \& Berghmans, I. (2015). A phenomenographic analysis of the implementation of competence-based education in higher education. Teaching and Teacher Education, 50, 1-12. https://doi.org/https://doi.org/10.1016/j.tate.2015.04.001

Kunnskapsdepartementet. (2018, 5. mars ). Yrkesfagelever får tidligere spesialisering. [Pressemelding]. Hentet fra https://www.regjeringen.no/no/aktuelt/yrkesfagelever-fartidligere-spesialisering/id2592683/

Lave, J. \& Wenger, E. (1991). Situated learning. Legitimate peripheral participation. Cambridge: Cambridge University Press.

Lester, S. \& Religa, J. (2017). "Competence" and Occupational Standards: Observations from Six European Countries. Education \& Training, 59(2), 201-214. https://doi.org/10.1108/ET-05-2016-0084

Louw, A. (2017). Kobling mellem skole og praktik på erhvervsuddannelserne. I K. E. Andreasen \& H. Duch (Red.), Forandringer i ungdomsuddannelserne: Overgange og indsatser (s. 93-114). Aalborg: Aalborg Universitetsforlag. Ungdomsliv.

Merriam, S. B. \& Tisdell, E. J. (2016). Qualitative Research: A Guide to Design and Implementation (4. utg.). San Fransisco: Jossey-Bass.

Norsk senter for forskningsdata. (udatert). Hentet 18.4. 2018 fra http://www.nsd.uib.no

Nyen, T. \& Tønder, A. H. (2012). Fleksibilitet eller faglighet?: En studie av innføringen av faget prosjekt til fordypning i Kunnskapsløftet. Oslo: Fafo. Hentet fra https://www.fafo.no/media/com_netsukii/20274.pdf

Olsen, O. J. \& Reegård, K. (2013). Læringsmiljø og gjennomføring i lærer- og elevperspektiv i tre yrkesfaglige opplæringsløp. I H. Høst (Red.), Kvalitet i fag- og yrkesopplæringen. Fokus på skoleopplæringen (s. 17-72). Oslo: NIFU. Hentet fra https://nifu.brage.unit.no/nifu-xmlui/handle/11250/280431

Patton, M. Q. (2015). Qualitative research \& evaluation methods: Integrating theory and practice (4. utg.). Los Angeles: Sage.

Rauner, F. (2007). International perspectives on teachers and lecturers in technical and vocational education. Dordrecht: Springer. 
Rønning, K. R. \& Nag, J. L. (2017, 07.03.2017). Mediedesign. Hentet 28.03. 2018 fra https://ndla.no/nb/node/169397?fag=156500

Schön, D. A. (1987). Educating the reflective practitioner. San Francisco, Calif: Jossey-Bass.

Schön, D. A. (1995). The reflective practitioner: How professionals think in action. Aldershot: Arena.

Utdanningsdirektoratet. (2006). Læreplan i felles programfag i Vg1 medier og kommunikasjon (MED1-01). Hentet 12.62018 fra https://www.udir.no/k106/MED1$\underline{01}$

Utdanningsdirektoratet. (2007). Programområde for medier og kommunikasjon - Læreplan i felles programfag Vg2 (MED2-01). Hentet 12.6. 2018 fra https://www.udir.no/k106/MED2-01

Utdanningsdirektoratet. (2008). Læreplan i mediegrafikerfaget VG3 / Opplæring i bedrift. Hentet 25.01. 2018 fra https://www.udir.no/k106/MGR3-01/Hele/Komplett_visning

Utdanningsdirektoratet. (2016a). Læreplan i felles programfag VG1 medieproduksjon. Hentet

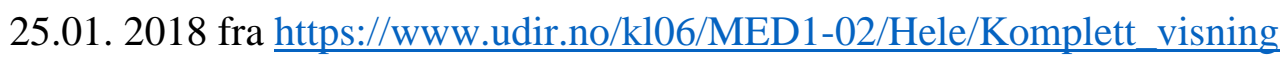

Utdanningsdirektoratet. (2016b). Lærlingeunders $\emptyset$ kelsen [The apprentice survey]. Hentet 10.8.2017 fra https://skoleporten.udir.no/rapportvisning/fag-ogyrkesopplaering/laeringsmiljoe/laerlingundersoekelsen/nasjonalt?enhetsid=00\&vurder ingsomrade $=6 \&$ underomrade $=54 \&$ skoletype $=6 \&$ skoletypemenuid $=2 \&$ sammenstilling $=1$

Utdanningsdirektoratet. (2018). Ny tilbudsstruktur for yrkesfaglige utdanningsprogram fra skoleåret 2020-21. Hentet 29.01. 2019 fra https://www.udir.no/contentassets/463eeb93ec1949dbae3a10d198a21bb6/nytilbudsstruktur.pdf

Utdanningsdirektoratet. (udatert). Studieforberedende utdanningsprogram Medier og kommunikasjon. Hentet 25.01. 2018 fra https://www.udir.no/k106/ME

Vibe, N. (2012). Virksomhet det fjerde året etter grunnskolen. I M. W. Frøseth, E. Hovdhaugen \& E. Markussen (Red.), Strukturer og konjunkturer: Evaluering av Kunnskapsløftet. Sluttrapport fra prosjektet "Tilbudsstruktur, gjennomføring og 
kompetanseoppnåelse i videregående opplæring" (s. 147-169). Oslo: Nifu. Hentet fra https://nifu.brage.unit.no/nifu-xmlui/handle/11250/280897

Wahlgren, B. \& Aarkrog, V. (2012). Transfer. Kompetence i en professionel sammenhæng. Aarhus: Aarhus Universitetsforlag.

Young, M. (2004). Conceptualizing vocational knowledge: Some theoretical considerations. I H. Rainbird, A. Fuller \& A. Munro (Red.), Workplace learning in context. London: Routledge.

Zitter, I., Hoeve, A. \& de Bruijn, E. (2016). A Design Perspective on the School-Work Boundary: A Hybrid Curriculum Model. Vocations and Learning, 9(1), 111-131. https://doi.org/10.1007/s12186-016-9150-y

Aakernes, N. (2011). Hvordan organisere en meningsfull og yrkesrelevant opplæring på medier og kommunikasjon [How to organise a meningful and vocational relevant education in Media and Communication] (Master thesis in Vocational Pedagogy, Oslo and Akershus University College). Hentet fra http://hdl.handle.net/10642/909

Aakernes, N. (2018). From school to work: Coherence between learning in school and learning in workplaces for apprentices in the Media graphics programme in Norway. Nordic Journal of Vocational Education and Training, 8(1), 76-97. https://doi.org/10.3384/njvet.2242-458X.188176

\section{Biografi}

Nina Aakernes er ph.d.-kandidat ved OsloMet - storbyuniversitetet, Fakultet for lærerutdanning og internasjonale studier, hvor hun underviser på masterstudiet $\mathrm{i}$ yrkespedagogikk. Hun har bakgrunn som yrkesfaglærer på medier og kommunikasjon og førtrykk, og har svennebrev som reprotekniker (mediegrafiker). Hennes forskningsinteresser er relevant yrkesopplæring, yrkesdidaktikk og samarbeid skole og arbeidsliv

Hilde Hiim er professor ved OsloMet - storbyuniversitetet, Fakultet for lærerutdanning og internasjonale studier, hvor hun underviser på master- og ph.d. -nivå. Hennes forskerinteresser er lærerutdanning, yrkesutdanning, didaktikk og aksjonsforskning. Hun har gitt ut en rekke bøker og artikler på disse feltene, og har ledet flere større forskningsprosjekter. 